\title{
PENGARUH KUALITAS WEBSITE TERHADAP HEDONIC SHOPPING MOTIVATION DAN IMPULSE BUYING
}

\author{
Dwita Anggriani \\ Department of Management FEB UMM \\ E-mail : dwita.anggriani@gmail.com
}

\begin{abstract}
ABSTRAK
Penelitian ini dilakukan atas dasar adanya peningkatan jumlah toko retail online yang ada diindonesia, hal ini membuat persaingan dalam pasar online semakin kompetitif. Perusahaan dituntut tidak hanya dapat menyediakan bermacam - macam produk yang dibutuhkan, namun perusahaan juga harus mampu menyediakan website yang baik dan dapat menarik perhatian konsumen. Kegiatan berbelanja tidak dapat terlepas dari motivasi yang mendasarinya dan satu motivasi itu adalah motivasi hedonic dimana motivasi merupakan motivasi belanja untuk mendapatkan kesenangan semata. Ketika seseorang berbelanja secara hedonic, tanpa sadar dia akan melakukan sikap impulse buying atau pembelian tidak terencana. Motivasi hedonik dan sikap impulse buying merupakan prilaku konsumen yang sangat menguntungkan perusahaan. tujuan dari penelitian ini adalah untuk mengetahui pengaruh kualitas website terhadap motivasi hedonic dan sikap impulse buying pada website MatahariMall.com. Penelitian ini menggunakan metode kuantitatif dengan menyebarkan questioner kepada 100 orang pelanggan MatahariMall.com. Analisis data menggunakan Struktural Equation Model ( SEM ). Hasil analisis data menyimpulkan bahwa terdapat pengaruh yang signifikan antara kualitas website terhadap hedonic shopping motivation dan impulse buying.
\end{abstract}

Keywords: kualitas website, hedonic shopping motivation, impulse buying

\section{PENDAHULUAN}

Pertumbuhan pengguna internet di Indonesia terus mengalami peningkatan dari tahun ke tahun. Dilangsir di www.idea.or.id menurut hasil survey yang mengenai Statistik Pengguna dan Perilaku Pengguna Internet Indonesia tahun 2016 yang dilakukan APJII menyatakan bahwa Indonesia terus mengalami pertumbuhan pengguna Internet yang luar biasa, sehingga jumlah pengguna internet saat ini mencapai 132,7 Juta pengguna atau bisa dikatakan bahwa penetrasi internet di
Indonesia sudah melampaui setengah total penduduk Indonesia yakni sebesar 51,8\%. Angka tersebut juga jauh lebih tinggi dibandingkan hasil survei pengguna internet tahun 2014 yakni 88 Juta pengguna.

Pertumbuhan pengguna internet di Indonesia diiringin dengan pertubuhan retail online atau $e-$ commers karena berbelanja online saat ini sudah menjadi tren dan gaya hidup dikalangan masyarakat, semenjak kemunculan kaskus ditahun 1999 membuat perusahaan retail online semakian banyak 
bermunculan. Sekarang kegiatan berbelanja dapat dilakukan dimana saja dan kapan saja, banyaknya pilihan produk, kemudahan dan keamanan dalam bertransaksi masih menjadi faktor penting dalam proses berbelanja online.

Semakin bertambahnya jumlah retail online atau e-commerce di indonesia membuat persaingan antara perusahaan retail online semakin kompetitif. Perusahaan retail online harus mampu menghadirkan website penjualan yang memiliki kualitas baik sehingga menarik banyak pembeli potensial untuk berbelanja. Sebuah website tidak hanya digunakan untuk memasarkan suatu produk dan jasa saja tetapi juga untukmemberikan informasi - informasi lainnya yang menarik bagi pelanggan, seperti (berita-berita terkini, produk terbaru, dan lain sebagainya). Mengukur kualitas website sangat penting dilakukan terutama untuk mengetahui kelebihan dan kekurangan website agar dapat dilakukan perbaikan. Pengukuran kualitas website dapat dilakukan dengan metpde WebQual, WebQual merupakan suatu parameter yang digunakan untuk menilai kualitas dari sebuah website dari perspektif konsumen. Dalam penelitian sejenis dikatakan bahwa sukses tidaknya suatu toko online dapat diukur dari kemampuan penyelenggara toko online untuk menyediakan website yang menarik serta dapat mempertahankan konsumen(Kim \& Lee, 2006).

Tahun 2016 menjadi tahun berkembangnya toko online di Indonesia, terdapat 12 toko online terpopuler menurut www.id.techinasia.com dan MatahariMall masuk dalam urutan ke10 toko online terpopuler di Indonesia. MatahariMall.com memberikan fasilitas pelayanan yang terbaik untuk mendukung proses belanja online dengan aman, nyaman dan terpercaya. MatahariMall.com menawarkan beragam kemudahan untuk bertransaksi, seperti transfer antar bank, kartu kredit dengan cicilan 0\%, O2O (Online-to-Offline), COD (Cash on Delivery), dan metode lainnya. MatahariMall.com menyediakan ratusan ribu pilihan produk dengan harga terbaik dari segala kebutuhan, mulai dari fashion wanita, fashion pria, produk kecantikan, smartphone, power bank, laptop, gadget, elektronik, TV LED, hobi, makanan \& minuman, dan lainnya.

Ketika kita berbelanja pasti didasari oleh motivasi - motivasi tertentu salah satunya adalah motivasi hedonis dimana motivasi hedonis adalah motivasi berbelanja karena kesenangan, fantasi dan sosial atau kepuasan emosional. Motivasi hedonis didapat dari pengalaman - pengalaman berbelanja, jadi pengalaman positif dalam proses berbelanja dapat memicu proses berbelanja secara hedonis. Proses berbelanja secara hedonis dalam online shop seperti browsing akan menimbulkan sikap impulse buying, sikap impulse buying sendiri adalah sikap membeli barang secara tidak terencana. Pembelian tidak terencana dapat terjadi saat itu juga tanpa memperhatikan manfaat dari barang yang dibeli.

Berdasarkan uraian fenomena tersebut maka tujuan penelitian ini 
adalah untuk mengetahui pengarih kualitas website terhadap hedonic shopping motivation dan impulse buying. Penelitian ini mengajukan pertanyaan sebagai berikut: (1) Apakah Kualitas website berpengaruh signifikan terhadap prilaku hedonic shopping motivation?; (2) Apakah kualitas website berpengaruh signifikan terhadap keputusan impulse buying?; (3) Apakah prilaku Hedonic shopping motivation berpengaruh signifikan terhadap keputusan impulse buying?; ( 4) Apakah Ada pengaruh yang tidak langsung dan signifikan antara kualitas website terhadap impulse buying melalui hedonic shopping motivation?

\section{TINJAUAN PUSTAKA}

Hasil penelitian terdahulu yang meneliti hubungan antara kualitas website, hedonic shopping motivation dan impulse pernah dilakukan oleh (Alhasanah, 2014), (Furkonudin dkk, 2016), (Pasaribu \& Dewi, 2015). Hasil temuan mereka menyatakan bahwa kualitas website berpengaruh secara signifikan terhadap hedonic shopping motivation dan impulse buying.

Motivasi hedonik banyak ditemukan dalam lingkungan online, mereka yang memiliki motivasi hedonik lebih tertarik untuk mengunjungi situs belanja yang dirancang dengan baik, yang mudah dalam navigasi dan visual (Zhou, 2007). Kim dan Gupta (dalam Li, 2016) beranggapan bahwa ketika teknologi e-commerce dirasa terlalu kompleks dan sulit untuk belajar maka kenikmatan akan menurun, namun berbeda jika situs dapat dengan mudah dan cepat untuk belajar dan digunakan, maka kenikmatan akan meningkat serta menimbulkan kesenangan dalam penggunaan sistem informasi.

Lohse dan Spiller (dalam Li, 2016) menunjukkan bahwa persepsi kemudahan penggunaan mempengaruhi kepercayaan pelanggan online dan beberapa fitur situs e-commerce, seperti mudah pencarian, interaktif dan navigasi terkait dengan perspektif motivasi fungsional dan motivasi hedonis. Motivasi hedonis lebih banyak berperan dalam proses pengambilan keputusan online karena mengandalkan pengalaman positif dalam berintaksi dengan situs. H1 : Kualitas Website berpengaruh signifikan terhadap Hedonic shopping motivation.

Kepuasan yang didapat ketika melakukan berbelanja online secara tidak langsung akan menimbulkan sikap impulse buying. Sikap impulse buying sendiri terjadi karena adanya rangsangan - rangsangan secara visual yang membuat seseorang tidak menyadari mengalami desakan untuk melakukan pembelian. Parboteeahet al. dalam Liu, Li, \& Hu, 2013, berpendapat bahwa kemudahan dalam kegunaan dan kenikmatan yang didapat ketika mengakses situs adalah reaksi terhadap stimulus dirasakan, seperti adanya daya tarik visualdan informasi mendesak konsumen untuk membeli secara impulsif. Studi ini menemukan bahwa konsumen lebih cenderung merasa mendesak untuk membeli secara impulsive jika interaksi mereka dengan lingkungan belanja menyenangkan. (Wolfinbarger dan Gilly dalam Permana, 2012) Begitu juga dalam penelitian yang dilakukan 
(Suhari, 2008) menyatakan bahwa pembelian dipengaruhi oleh"efisiensi untuk pencarian (waktu cepat, mudahdalam penggunaan, dan usaha pencarian mudah), (2) value (harga bersaing dan kualitas baik), dan (3) interaksi (informasi, keamanan, load time, dannavigasi)". Beberapa penelitian yang sejenis juga menyatakan bahwa kualitas website berpengaruh siqnifikan dalam pembelian secara impulsif. $\mathrm{H} 2$ : Kualitas Website berpengaruh signifikan terhadap Impulse Buying

Selain stimulus - stimulus atau rangsangan dari lingkungan mempengaruhi terjadinya pembelian impulse, faktor personal juga berpengaruh. Pembelian secara impulse biasanya terjadi karena pengalaman - pengalaman berbelanja terlebih dahulu, seseorang yang sering berbelanja hanya karena untuk mengisi waktu luang (hedonis) memiliki kecendurungan bersikap impulse buying dalam membelanjakan uangnya.

Hasil penelitian lain tentang prilaku pembelian impulse online yang dilakukan (Haq \& Abbasi, 2016) menemukan bahwa motif hedonic berpengaruh secara signifikan sebagai mediator tunggal sikap impulse buying, dapat dikatakan bahwa kecenderungan seseorang melakukan konsumsi secara hedonis akan menciptakan perilaku pembelian impuls. Verplanken dan Herabadi dalam Muruganantham \& Bhakat, 2013, menemukan hasil yang sama dalam penelitian yang sejenis danmenyatakan bahwa membeli impulse sering dikaitkan dengan individu yang ingin melarikan diri dari negatif psikologispersepsi seperti rendah diri, perasaan negatif, atau suasana hati. H3 : Hedonic shopping motivation berpengaruh signifikan terhadap impulse buying.

Seseorang yang memiliki kecenderungan berbelanja karena niat hedonic, lebih sering menghabiskan banyak waktu menjelajahi sebuah website, dalam proses menjelajahi sebuah website seseorang akan mendapatkan pengalaman - pengalam baru dan dapat menilai bagus tidaknya sebuah website. Rangsangan - rangsangan yang didapat akan membuat sesorang melakukan pembelian secara terencana. dalam penelitian yang dilakuan Maka dapat dirumuskan hipotesa sebagai berikut. H4 : Ada pengaruh yang tidak langsung dan signifikan antara kualitas website terhadap impulse buying melalui hedonic shopping motivation

\section{METODE PENELITIAN}

Populasi dalam penelitian ini adalah follower fanpage MatahariMall.com yang pernah berbelanja selama periode bulan juni - agustus 2016 dengan jumlah yang tak terhingga. Penelitian ini menggunakan purposive sampling untuk menentukan jumlah populasinya, purposive sampling dapat dikatakan sebagai cara pengambilan sampel secara sengaja sesuai dengan persyaratan sampel yang diperlukan. Jumlah sampel yang digunakan dalam penelitian ini adalah 100 responden dan skala pengukuran yang digunakan adalah dengan skala likert. 


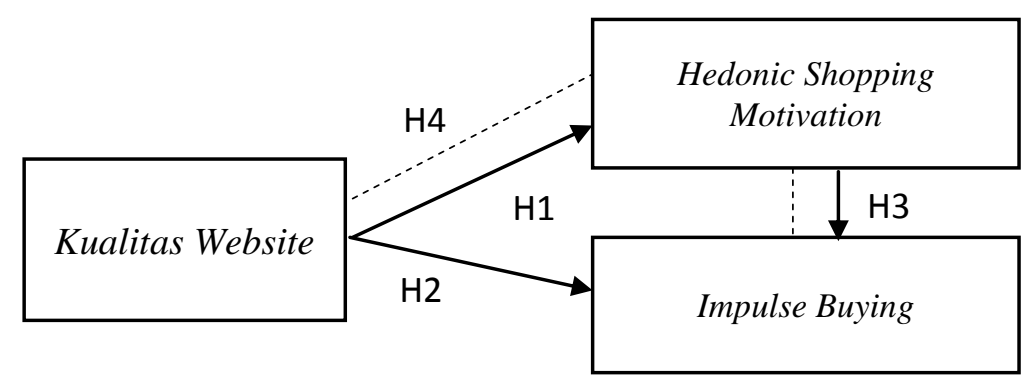

Gambar 1. Kerangka Konseptual Penelitian

\section{HASIL PENELITIAN DAN PEMBAHASAN}

Berdasarkan hasil penelitian yang dilakukan terhadap 100 pelanggan MatahariMall,com, diketahui beberapa karakteristik responden yang akan ditunjukkan oleh Tabel 1,2,3 dan 4 berikut ini:

Tabel 1. Karakteristik responden berdasarkan domisi tempat tinggal

\begin{tabular}{cccc}
\hline No & Domisili & Frekuensi & $\begin{array}{c}\text { Presentase } \\
(\%)\end{array}$ \\
\hline 1 & Jawa & 84 & 84 \\
2 & Luar Jawa & 16 & 16 \\
& Jumlah & 100 & 100 \\
\hline
\end{tabular}

Tabel 1 menunjukkan sebagian besar responden penelitian ini berasal dari pulau jawa sebanyak 84 orang pelangan. Karakteristik responden berdasakan usia Karakteristik responden berdasarkan usia, dapat dilihat pada Tabel 2:
Tabel 2. Karakteristik responden berdasarkan usia

\begin{tabular}{llll}
\hline No & Usia & Jumlah & Pesentase \\
\hline 1 & $18-25$ & 25 & $25 \%$ \\
2 & $25-32$ & 63 & $63 \%$ \\
3 & $32-50$ & 12 & $12 \%$ \\
& Total & 100 & $100 \%$ \\
\hline
\end{tabular}

Tabel 3. Karakteristik Responden Berdasarkan Jenis

\begin{tabular}{cccc}
\multicolumn{4}{c}{ Kelamin } \\
\hline \multirow{2}{*}{ No } & $\begin{array}{c}\text { Jenis } \\
\text { Kelamin }\end{array}$ & Jumlah & Persentase \\
\hline 1 & Pria & 38 & $38 \%$ \\
2 & Wanita & 61 & $61 \%$ \\
3 & Tidak & 1 & $1 \%$ \\
& memilih & 100 & $100 \%$ \\
\hline & Total & 100
\end{tabular}

Berdasarkan Tabel 3. Dapat diketahuibahwa sebagian besar responden penelitian ini adalah wanita, yaitu sebanyak 61 orang atau $61 \%$. Hal ini memberikan gambaran bahwa tren berbelanja online masih didominasi oleh wanita.

Tabel 4. Karakteristik Responden Berdasarkan Pekerjaan

\begin{tabular}{llll}
\hline No & Pekerjaan & Jumlah & Persentase \\
\hline 1. & Wiraswasta & 21 & $21 \%$ \\
2. & PNS & 9 & $9 \%$ \\
3. & Pegawai Swasta & 32 & $32 \%$ \\
4. & $\begin{array}{l}\text { Pelajar / Mahasiswa } \\
\text { 5. }\end{array}$ Pengurus rumah tangga / ibu & 9 & $9 \%$ \\
& $\begin{array}{l}\text { rumah tangga } \\
\text { 6. }\end{array}$ & & $9 \%$ \\
7. & Tidak memilih & 7 & $7 \%$ \\
\hline Total & 5 & $5 \%$ \\
\hline
\end{tabular}


Tabel 4. menunjukkan pelanggan MatahariMall berasal dari latar belakang pekerjaan yang beragam, namun yang paling banyak melakukan transaksi belanja adalah pegawai swasta dengan jumlah 32 orang atau $32 \%$.

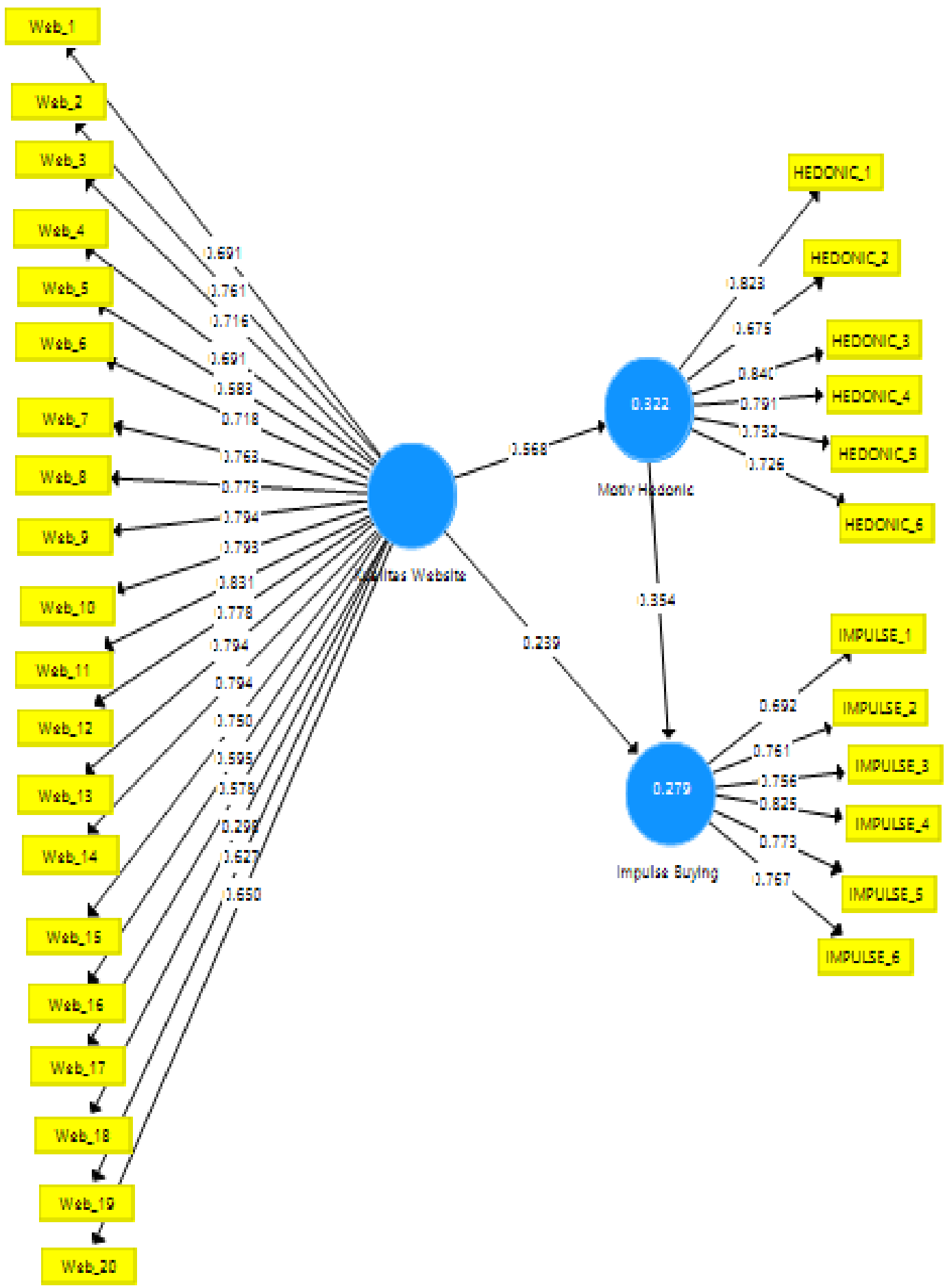

Gambar 1. Model pengukuran 


\section{SIMPULAN}

Berdasarkan hasil penelitian yang telah dijelaskan tersebut, maka dapat disimpulkan guna menjawab rumusan masalah penelitian sebagai berikut. Kualitas website berpengaruh signifikan terhadap hedonic shopping motivastion. Artinya bahwa kualitas website mataharimall.com sudah dapat menarik pelanggan yang memiliki kecendurungan berbanja dengan niat hedonic shopping atau menimbulkan niat hedonic. Hal ini dapat dilihat dari kemudahan penggunaan website, banyaknya jumlah produk yang dijual dan kemanan transaksi. Semakin baik sebuah website maka semakin banyak pula keutungan yang didapat perusahaan karena dapat menari pelanggan potensial terutama mereka yang memiliki kecendurang berbelanja karena niat hedonik.

Kualitas website berpengaruh signifikan terhadap sikap impulse buying. Artinya bahwa website mataharimall,com dirasa dapat menimpulkan sikap impulse buying, hal ini dapat terjadi karena banyaknya diskon yang ditawarkan mataharimall.com.

Hedonic shopping motivation berpengaruh signifikan terhadap impulse buying. Dapat diartikan bahwa sesorang yang melakukan belanja karena niat hedonic secara tidak sadar akan melakukan pembelanjaan secara tidak terencana.

Hedonic shopping motivasi berfungsi sebagai mediasi antara kualitas website terhadap impulse buying. Artinya bahwa hedonic shopping motivation dan kualitas website menjadi dua variabel yang saling mendukung untuk menciptakan sikap impulse buying.

Perilaku bebelanja online sangatlah luas untuk diteliti lebih lanjut, maka dari itu peneliti berharap akan ada pengembangan dari penelitian yang dilakukan dengan menambah variabel kepuasan pelanggan dan loyalitas pelanggan, agar dapat menambah wawasan baru.

\section{DAFTAR PUSTAKA}

Apjii ( 2016 ). Hasil Survei Internet Tahunan, diakses 26 agustus 2016 dari https://www.idea.or.id/berita/det ail/hasil-survei-internet-tahunanapjii-2016

Barnes S, V. (2002). An integrative approach to the assessment of ecommerce quality. Journal of Electronic Commerce Research, 3(2), 114-127. http://doi.org/10.1080/0022389 1.2013 .770400

Chang, H.-J., Eckman, M., \& Yan, R.-N. (2011). Application of the Stimulus-Organism-Response model to the retail environment: the role of hedonic motivation in impulse buying behavior. The International Review of Retail, Distribution and Consumer Research, 21(3), 233-249. http://doi.org/10.1080/0959396 9.2011.578798

Chaudhuri, S. (2015). A Study on the Impact of Hedonic Shopping Value on Impulse Buying Among Consumers in Kolkata. Journal of Arts, 159160(2).

Citra, E. (2015). Pengaruh Hedonic Shopping Motivation Terhadap Impulse Buying Pada Toko Online (Studi Pada 
Berrybenka.com), 5-10.

Foroughi, A., Buang, N. A., Senik, Z. C., Hajmirsadeghi, R. S., \& Bagheri, M. M. (2014). The causes of impulse buying behavior among iranian shoppers. Asian Social Science, 10(21), 64-72. http://doi.org/10.5539/ass.v10n2 $1 \mathrm{p} 64$

Furkonudin dkk. (2016). Evaluasi Kualitas Layanan Website ECommerce, 6-7.

Gültekin, B., \& Hacettepe, L. Ö. (2012). The Influence of Hedonic Motives and Browsing On Impulse Buying. Journal of Economics \& Behavioral Studies, 4(3), 180-189. http://doi.org/2220- 6140

Hadi Pramana, Aditya ( 2016 ). Toko Online Terpopuler di Indonesia, diakses 26 agustus 2016 dari https://id.techinasia.com/tokoonline-populer-di-indonesia

Haq, M. A., \& Abbasi, S. (2016). Indirect Impact of Hedonic Consumption and Emotions on Impulse Purchase Behavior: A Double Mediation Model, 3(2), 108-122.

http://doi.org/10.20547/jms.201 4.1603202

Hetharie, J. A. (2012). Model Kecenderungan Pembelian Impulsif ( Studi pada Konsumen Matahari

Departement Store Kota Ambon ), 11(3).

HM, Jogiyanto ( 2011 ). Konsep dan Aplikasi Structural Equation Model( SEM ) Berbasis Varian dalam Penelitian Bisnis. Yogyakarta : STIM YKPN

Kim, S., \& Lee, Y. (2006). Global online marketplace: a cross- cultural comparison of website quality. International Journal of Consumer Studies, 30(6), 533543. http://doi.org/10.1111/j.14706431.2006.00522.x

Li, Y. (2016). Empirical Study of Influential Factors of Online Customers , Repurchase Intention, 48-60. http://doi.org/10.4236/ib.2016.8 3006

Lim Pei Ling, B., Yazdanifard, R., Pei Ling, L., \& Yazdanifard, R. (2015). What Internal and External Factors Influence Impulsive Buying Behavior in online Shopping? Global Journal of Management and Business Research, 15(5).

Liu, Y., Li, H., \& Hu, F. (2013). Website attributes in urging online impulse purchase: An empirical investigation on consumer perceptions. Decision Support Systems, 55(3), 829837.

http://doi.org/10.1016/j.dss.201 3.04.001

Malhotra, N. K. (2005). Riset Pemasaran (Pendekatan Terapan) Terjemahan Soleh Rusyadi M. Jakarta PT.Indeks Kelompok Gramedia

Mamang Sangadji, Etta dan Sopiah ( 2013 ). Prilaku Konsumen. Yogyakarta : Cv Andi Offset

Muruganantham, G., \& Bhakat, R. S. (2013). A Review of Impulse Buying Behavior. International Journal of Marketing Studies, 5(3), 149-160. http://doi.org/10.5539/ijms.v5n3 p149

Pasaribu, L. O., \& Dewi, C. K. (2015). Pengaruh Hedonic 
Shopping Motivation Terhadap Impulse Buying Pada Toko Online: Studi Pada Toko Online Zalora. Jurnal Bina Ekonomi, 19(72), 159-170.

Permana, D. (2012). Analisis Faktor

- Faktor Yang Memepengaruhi Niat Pembelian Online Dengan Motivasi Belanja Konsumen Sebagai Pemoderasi.

Suhari, Y. (2008). Desain Web Berorientasi Konsumen, XII(2), 178-182.

Suhartini. (2011). Analisis FaktorFaktor Yang Mempengaruhi Motif Belanja Secara Online Di Komunitas Kaskus Semarang, 1-32.

Suhermin, N. P. (2015). Pengaruh Motivasi Belanja Hedonik Terhadap Pembelian Impulsif Konsumen Matahari Surabaya, 4, 1-17.

Verhagen, T., \& Van Dolen, W. (2011). The influence of online store beliefs on consumer online impulse buying: A model and empirical application. Information and Management, 48(8), 320-327. http://doi.org/10.1016/j.im.2011 .08 .001

Wells, J. D., Parboteeah, D. V., \& Valacich, J. S. (2011). Journal of the Association for Information Online Impulse Buying: Understanding the Interplay between Consumer Impulsiveness and Website Quality * Online Impulse Buying: Understanding the Interplay between Consumer Impulsiveness and Website Quality. Journal of the Association for Information Systems, 12(1), 32-56.

Zhou, L. (2007). - A Criticial Survey Of Consumer Factors In Online Shopping, 8(1), 41-62. 